\title{
Secondary prevention in minor ischemic stroke with antiplatelet treatment. Systematic review and meta-analysis of comparative studies with aspirin under non-inferiority criteria.
}

\author{
Gilberto Viæcaíno ${ }^{1,2}$, Juan Paul Montalvo Herdoiæa ${ }^{3}$, Aline Siteneski ${ }^{1}$ \\ and Wendy Tauris Navarro ${ }^{3}$ \\ ${ }^{1}$ Instituto de Investigación, Universidad Técnica de Manabí, Portoviejo, Ecuador. \\ ${ }^{2}$ Universidad del Zulia, Facultad de Medicina, Instituto de Investigaciones Clínicas \\ "Dr. Américo Negrette", Maracaibo, Venezuela. \\ ${ }^{3}$ Facultad de Ciencias de la Salud, Escuela de Medicina, Universidad Técnica de Manabí, \\ Portoviejo, Ecuador.
}

Key words: secondary prevention; ischemic stroke; antiplatelet treatment; meta-analysis; non-inferiority.

\begin{abstract}
Minor ischemic stroke is the most frequent presentation of cerebral vascular disease and treatment with antiplatelet drugs can be used for the prevention of its recurrence. This systematic review and meta-analysis was aimed to assess non-inferiority criteria about the effect in the comparison of different antiplatelet schemes using aspirin as active control. Twelve randomized studies with a total of 52204 patients were chosen. All met the inclusion criteria with minor recurrent ischemic stroke as end point and any extracranial bleeding as safety event. The results showed a significant risk reduction of $22 \%$ [RR (95\% CI) $=0.78(0.72-0.84), \mathrm{p}<0.0001, \mathrm{NNT}$ : 67] in the recurrence of ischemic events with any antiplatelet drug (combined or not with aspirin) versus aspirin alone and there were no differences in the bleeding risk [RR $(95 \% \mathrm{CI})=1.02(0.74$ 1.41), $\mathrm{p}=0.899$, NNH: 500]. Dual antiplatelet therapy (DAPT) and cilostazol were more effective compared with aspirin alone $(22 \%$ and $32 \%$ risk reduction respectively) but only cilostazol showed a higher reduction (52\%) of bleeding events. In conclusion, although in some instances equivalence was demonstrated, a clinical superiority in the risk reduction for recurrent ischemic stroke of any antiplatelet treatment versus aspirin alone was observed. With the sole exception of the cilostazol trials there was an increase of the bleeding risk when the antiplatelet drugs treatments were compared with aspirin alone.
\end{abstract}

Corresponding Author: Gilberto Vizcaíno. Instituto de Investigación, Universidad Técnica de Manabí. Universidad del Zulia, Facultad de Medicina, Instituto de Investigaciones Clínicas "Dr. Américo Negrette", Maracaibo, Venezuela. Phone: +593 992221044. E-mail: gilvizeaino@gmail.com 


\title{
Prevención secundaria en el ictus isquémico menor con el tratamiento antiplaquetario. Revisión sistemática y metanálisis de estudios comparativos con aspirina bajo criterios de no inferioridad.
}

\author{
Invest Clin 2020; 61 (3): 265-282
}

Palabras clave: prevención secundaria; accidente cerebrovascular isquémico; tratamiento antiplaquetario; metanálisis; no inferioridad.

Resumen. El accidente cerebrovascular (ictus) isquémico menor es la presentación más frecuente de enfermedad vascular cerebral y se puede utilizar el tratamiento con fármacos antiplaquetarios para la prevención de su recurrencia. Esta revisión sistemática y metanálisis tuvo como objetivo evaluar los criterios de no inferioridad sobre el efecto en la comparación de diferentes esquemas antiplaquetarios que usan aspirina como control activo. Se eligieron doce estudios aleatorios con un total de $\mathbf{5 2 . 2 0 4}$ pacientes. Todos cumplieron los criterios de inclusión para ictus isquémico recurrente menor como desenlace primario y hemorragia extracraneal como evento de seguridad. Los resultados mostraron una reducción significativa del riesgo del 22\% [RR (IC 95\%) $=0,78$ $(0,72-0,84), p<0,0001$, NNT: 67] en la recurrencia de eventos isquémicos con cualquier fármaco antiplaquetario (combinado o no con aspirina) versus aspirina sola y no hubo diferencias en el riesgo de hemorragia $[\mathrm{RR}(\mathrm{IC}$ 95\%) $=1.02$ (0.74-1.41), $\mathrm{p}=0.899, \mathrm{NNH}$ : 500]. La terapia antiplaquetaria dual (DAPT) y el cilostazol fueron más efectivos en comparación con la aspirina sola (22\% y $32 \%$ de reducción de riesǵo respectivamente) pero solo el cilostazol mostró una mayor reducción (52\%) de los eventos hemorrágicos. En conclusión, aunque en algunos casos se demostró la equivalencia, se observó una superioridad clínica en la reducción del riesgo de accidente cerebrovascular isquémico recurrente de cualquier tratamiento antiplaquetario versus aspirina sola. Con la única excepción de los ensayos con cilostazol, hubo un aumento del riesǵo de hemorragia cuando los tratamientos con fármacos antiplaquetarios se compararon con la aspirina sola.

Received: 05-06-2020 Accepted: 10-08-2020

\section{INTRODUCTION}

Acute cerebrovascular disease (ACD) is defined as a focal neurological deficit of generally arterial origin, lasting more than 24 hours and can be classified as ischemic stroke $(85 \%)$ or intracranial hemorrhage (15\%) $(1,2)$. ACD can be stratified by the risk factors and preventive measures. Nonfatal ischemia in the acute ischemic stroke is diagnosed by the sudden onset of a new or growing neurological deficit that persists for more than 24 hours; an event resulting in an increase in disability of at least one degree on the modified Rankin scale (measurement scale degree of disability or dependence on the daily activities of people with Stroke and neurological disability) (3). Another of the recognized tools for predicting a clinical stroke is the Framingham's stroke risk 
profile, which combines modifiable and nonmodifiable risks (4). The stratification can be done with different scales such as the $\mathrm{Na}$ tional Institute of Health Stroke Scale (NIHSS) (5), the ABCD2 (age, blood pressure, clinical, duration and diabetes type 2 scale (6), and its recently modified as ABCD3-I including diffusion-weighted imaging (7) to classify the severity or the risk of a cerebrovascular event and its treatment), which highlights the importance of adequate anamnesis and physical examination of patients followed by neuroimaging (MRI) diaǵnosis.

Brain lacunar infarets are usually known as a part of the small-vessel disease (SVD) as one of the main manifestation of ischemic stroke. Lacunar infarcts have $<1.5$ em diameter that result from occlusion of a single penetrating artery usually located in the basal ganglia, corona radiate, internal capsule, thalamus and the brainstem. Clinically lacunar infarets are recognized in five types of presentations: pure motor hemiparesis, pure sensory stroke, sensory-motor stroke, dysarthria-clumsy hand syndrome and ataxic hemiparesis (8). The clinically defined transient ischemic attacks (TIA), may not be transient at the tissue level, and be considered as a part of the ischemic stroke spectrum. A TIA is not a pathological entity by itself; it is a milder form in the spectrum of ischemia and is therefore a form of presentation of cerebrovascular disease (8).

These recent years have been marked by changes regarding the therapeutic behavior adopted to treat the disease. Currently, many patients with acute ischemic stroke are benefited from treatments such as intravenous thrombolysis and endovascular thrombectomy (5). The main measures indicated in the treatment guidelines for ACD include: a) thrombolytic measures within three hours of the ischemic event (thrombolysis or thrombectomy), and b) antiplatelet, antithrombotic or anticoagulant treatment to avoid stroke recurrence $(2,5)$. The secondary prevention of ischemic stroke uses antiplatelet agent treatment for non-cardioembolic cerebral ischemic events and oral anticoagulation for cardioembolic ischemic events (e.g. Atrial Fibrillation) (9). According to the 2018 guidelines for the treatment of ACD, aspirin (for its irreversible inhibition effect of cyclooxygenase-1) has been the treatment of choice for ischemic stroke from the second half of the twentieth century to the present day $(5,10-12)$. The use of receptor inhibitors for adenosine diphosphate (ADP) type $\mathrm{P} 2 \mathrm{Y}_{12}$ has boomed in the two decades of the 21 st century (thienopiridines such as ticlopidine, clopidogrel, prasugrel and non-tienopiridines such as ticagrelor, cangrelor and elinogrel) (13), some of them indicated as dual therapy with aspirin versus aspirin alone. Moreover, platelet phosphodiesterase inhibitors (dipyridamol and cilostazol) have been used as antiplatelet agents in the treatment of ischemic stroke by the prevention of cyclic AMP inactivation and irreversible inhibition of platelet function $(14,15)$. The use of other antiplatelet agents with a different mechanism of action has been published such as the so-called platelet receptor antagonists for Glycoprotein IIb-IIIa: tirofiban (16), eptifibatide (17-19) and abxicimab $(20,21)$. However, the studies were performed in small population samples and the results did not support its ordinary use in clinical practice, so the 2018 guidelines on the treatment of acute ischemic accident do not recommend its administration (5).

This systematic review proposes to conduct an analysis of comparative studies between aspirin as active control and studies with antiplatelet agents, using dual therapy (including aspirin) or monotherapy versus aspirin, with a no inferiority approach for effectiveness of clinical trials in reducing events (recurrence) in patients with ischemic stroke. The triple therapy versus aspirin alone will not be included in this systematic review because of its adverse effects (increased risk of bleeding) and actually, this type of treatment should not be indicated in the treatment of ischemic stroke (22). 


\section{METHODOLOGY}

\section{Search strategies}

The present review focus exclusively on antiplatelet treatment for non-cardioembolic minor ischemic stroke (summarized in Table I). A twenty year-span (2000-2019) search of bibliography was conducted through PUBMED by MEDLINE, Google Scholar and Cochrane collaboration (Cochrane Systematic Reviews), under the following terminology MESH (Medical Subject Headings): stroke, ischemic stroke, transient ischemic attack (TIA), ischemic recurrent stroke, minor stroke, non-cardioembolic stroke, ischemic lacunar stroke, aspirin, clopidogrel, prasugrel, ticagrelor, cilostazol, dipyridamole and dual antiplatelet therapy using AND as the connector for the term "Non-inferiority studies". In relation to exclusion criteria, only randomized clinical trials with more than 300 patients were included in this systematic review and there was no substantial difference (more than 5\%) among the number of subjects in the active intervention and control groups. Other reasons for excluding articles are exposed in Fig. 1. Previous systematic reviews

TABLE I

MAIN CHARACTERISTICS OF ANTIPLATELET DRUGS IN THE TREATMENT OF ISCHEMIC STROKE.

\begin{tabular}{|c|c|c|c|c|c|}
\hline $\begin{array}{l}\text { Antiplatelet } \\
\text { drug }\end{array}$ & $\begin{array}{l}\text { Drug type and } \\
\text { Mechanism of action }\end{array}$ & $\begin{array}{l}\text { Type of } \\
\text { administration }\end{array}$ & $\begin{array}{l}\text { Half } \\
\text { life }\end{array}$ & $\begin{array}{l}\text { Duratión } \\
\text { of the effect }\end{array}$ & Adverse effects \\
\hline Aspirin & $\begin{array}{l}\text { acetyl salicílic } \\
\text { acid, inhibitor of } \\
\text { cycloxigenase-1 }\end{array}$ & Oral & $12 \mathrm{~h}$ & 10 days & G.I. hemorrhage \\
\hline Ticlopidine* & $\begin{array}{l}\text { Tienopiridine, } \mathrm{P} 2 \mathrm{Y} 12 \\
\text { receptor inhibitor }\end{array}$ & Oral & $12-22 \mathrm{~h}$ & $15 \mathrm{~d}$ & $\begin{array}{l}\text { ThrombocytopeniaTTP, } \\
\text { G.I.symptoms, aplastic } \\
\text { bone marrow }\end{array}$ \\
\hline Clopidogrel & $\begin{array}{l}\text { Tienopiridine } \mathrm{P} 2 \mathrm{Y} 12 \\
\text { receptor inhibitor }\end{array}$ & Oral & $8 \mathrm{~h}$ & $5-10 d$ & $\begin{array}{l}\text { Neutropenia, } \\
\text { thrombocytopenia, } \\
\text { allergic reactions }\end{array}$ \\
\hline Prasugrel & $\begin{array}{l}\text { Tienopiridine, } \mathrm{P} 2 \mathrm{Y} 12 \\
\text { receptor inhibitor }\end{array}$ & Oral & $12 \mathrm{~h}$ & $5-9 d$ & G.I. hemorrhage \\
\hline Ticagrelor & $\begin{array}{l}\text { Cyclopentiltriazol } \\
\text { primidine, P2Y12 } \\
\text { receptor inhibitor }\end{array}$ & Oral & $8-12 \mathrm{~h}$ & $5 \mathrm{~d}$ & Dyspnea, arrhythmia \\
\hline Cangrelor & $\begin{array}{l}\text { ATP Analogue, } \mathrm{P} 2 \mathrm{Y} 12 \\
\text { receptor inhibitor }\end{array}$ & I.V. & $2-5 \min$ & $1 \mathrm{~h}$ & $\begin{array}{l}\text { Dyspnea hipersensibility } \\
\text { reactions }\end{array}$ \\
\hline Elinogrel & $\begin{array}{l}\text { direct antagonist of } \\
\text { P2Y12receptor }\end{array}$ & Oral / I.V. & $\begin{array}{l}12-14 \mathrm{~h} \\
\text { oral, } 50 \\
\text { min I.V. }\end{array}$ & $\begin{array}{l}8-24 \mathrm{~h} \\
\text { oral, } \\
2 \mathrm{~h} \mathrm{I}: \mathrm{V} .\end{array}$ & $\begin{array}{l}\text { Dyspnea, } \\
\text { hepatotoxicity }\end{array}$ \\
\hline Dipyridamol & $\begin{array}{l}\text { platelet } \\
\text { phosphodiesterase } \\
\text { Inhibitor }\end{array}$ & Oral & $12 \mathrm{~h}$ & $5 \mathrm{~d}$ & $\begin{array}{l}\text { headache, dizziness, } \\
\text { diarrhea }\end{array}$ \\
\hline Cilostazol & $\begin{array}{l}\text { platelet } \\
\text { phosphodiesterase } 3 \\
\text { Inhibitor }\end{array}$ & Oral & $11-13 \mathrm{~h}$ & $5 \mathrm{~d}$ & $\begin{array}{l}\text { headache, tachycardia, } \\
\text { diarrhea }\end{array}$ \\
\hline Vorapaxar & $\begin{array}{l}\text { platelet thrombin } \\
\text { receptor Inhibitor } \\
\text { (PAR-1) }\end{array}$ & Oral & $2 \mathrm{~h}$ & $7-12 \mathrm{~d}$ & $\begin{array}{l}\text { headache, dizziness, } \\
\text { G.I. symptoms, } \\
\text { arthralgia, erythema }\end{array}$ \\
\hline
\end{tabular}

Taken and modified from Campuzano Maya G (25). *currently not indicated. 


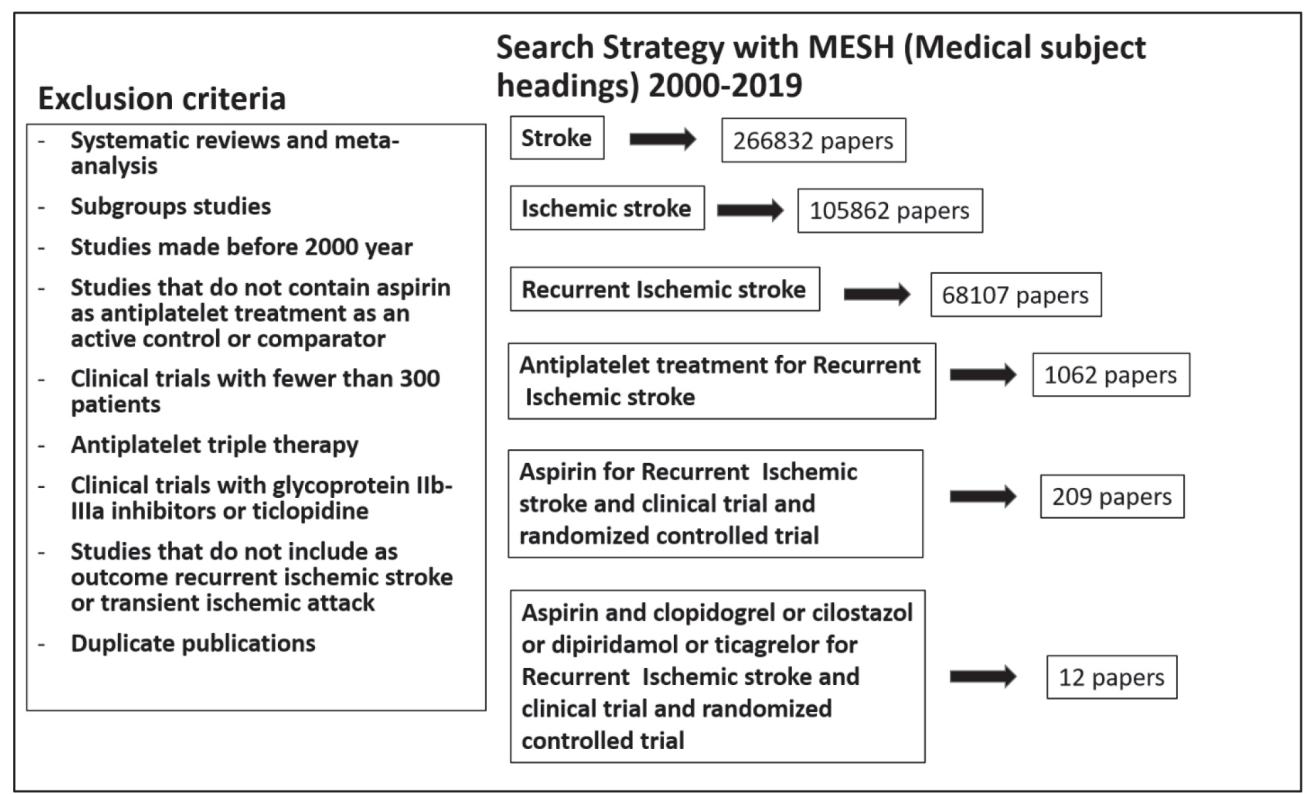

Fig. 1. Search strateǵy with MESH terminoloǵy and exclusion criteria.

and meta-analysis were only considered for the discussion part. The Jadad scale for randomized studies was applied for calculation of the quality report of each study (23) and the Cochrane risk of bias tool to assess for individuals' trials (24).

The primary end point for effectiveness was recurrent ischemic stroke and TIA, when a study presented a composite outcome (death, myocardial infaretion and stroke), only data corresponding to recurrent ischemic stroke were extracted as an event to be analyzed. The exclusion criteria were: disabling stroke (modified Rankin score 4 out of 6); risk factors for cardioembolic sources such as atrial fibrillation; subcortical infaretion with diameter $>1.5 \mathrm{~cm}$; recent or remote cortical infarction confirmed by MRI; and a history of intracerebral hemorrhage other than microhemorrhage or cortical ischemic stroke. Among safety or secondary events, major bleeding was chosen according to GUSTO (Global Utilization of Streptokinase and Tissue Plasminogen Activator for Occluded Coronary Arteries) definition (25) or PLATO bleeding definition (26). Some studies analyzed only describe hemorrhagic events without discrimination of the type of bleeding, cases with intracranial hemorrhage were not considered and these were excluded from the study for both effectiveness and safety.

According to search strategies, Table II shows the studies that met the inclusion requirements and were identified and classified as follows: a) Six studies with clopidogrel-aspirin dual therapy (DAPT) versus aspirin as active control: CHARISMA (27), SPS3 (28), CHANCE 2013 (29), Coté (30), COMPRESS (31), POINT (32); b) four studies with cilostazol versus aspirin: CASISP (33), CSPS-2 (34), PICASSO (35), CSPS. com (36); c) one study with ticagrelor versus aspirin: SOCRATES (37) and d) one study of dipyridamole dual therapy (dipyridamole-aspirin versus aspirin): ESPRIT (38).

\section{Criteria for non-inferiority studies}

In "non-inferiority" trials, the main objective is to demonstrate that the efficacy between two treatments is similar, one called new treatment and the other called active control or standard treatment, so there is a need for comparative evidence. The question to ask when trying to conduct non-inferiority studies is: ¿Is the new treatment at least as effective 
TABLE II

COMPARATIVE STUDIES OF PLATELET AGENTS VERSUS ASPIRIN IN SECONDARY PREVENTION OF ISCHEMIC STROKE.

\begin{tabular}{|c|c|c|c|c|c|}
\hline $\begin{array}{l}\text { STUDY } \\
\text { (YEAR) } \\
\text { (REF) }\end{array}$ & COMPARISON & $\begin{array}{l}\text { DESING } \\
\text { AND } \\
\text { DURATION }\end{array}$ & PATIENTS & $\begin{array}{l}\text { PRIMARY } \\
\text { OUTCOME }\end{array}$ & $\begin{array}{l}\text { SECURITY } \\
\text { OUTCOME }\end{array}$ \\
\hline $\begin{array}{l}\text { CHARISMA } \\
(2006)^{27}\end{array}$ & $\begin{array}{l}\text { CLOPIDOGREL + } \\
\text { ASPIRIN } \\
\text { VS ASPIRIN + PLACEBO }\end{array}$ & $\begin{array}{l}\text { RDBPC } \\
\text { 2-3 YEARS }\end{array}$ & $\begin{array}{l}15603 \\
\text { DAPT: } 7802 \\
\text { ASA: } 7801\end{array}$ & $\begin{array}{l}\text { COMPOSITE*/ } \\
\text { RECURRENT } \\
\text { ISCHEMIC STROKE } \\
+ \text { TIA }\end{array}$ & $\begin{array}{l}\text { MAJOR } \\
\text { EXTRACRANIAL } \\
\text { HEMORRHAGE }\end{array}$ \\
\hline $\begin{array}{l}\text { SPS3 } \\
(2012)^{28}\end{array}$ & $\begin{array}{l}\text { CLOPIDOGREL + } \\
\text { ASPIRIN } \\
\text { VS ASPIRIN + PLACEBO }\end{array}$ & $\begin{array}{l}\text { RDBPC } \\
\text { 3-5 YEARS }\end{array}$ & $\begin{array}{l}3020 \\
\text { DAPT: } 1517 \\
\text { ASA: } 1503\end{array}$ & $\begin{array}{l}\text { STROKE/RECURRENT } \\
\text { ISCHEMIC } \\
\text { STROKE + TIA }\end{array}$ & $\begin{array}{l}\text { MAJOR } \\
\text { EXTRACRANIAL } \\
\text { HEMORRHAGE }\end{array}$ \\
\hline $\begin{array}{l}\text { CHANCE } \\
(2013)^{29}\end{array}$ & $\begin{array}{l}\text { CLOPIDOGREL+ } \\
\text { ASPIRIN } \\
\text { VS ASPIRIN + PLACEBO }\end{array}$ & $\begin{array}{l}\text { RDBPC } \\
90 \text { DAYS }\end{array}$ & $\begin{array}{l}5170 \\
\text { DAPT: } 2584 \\
\text { ASA: } 2586\end{array}$ & $\begin{array}{l}\text { STROKE/RECURRENT } \\
\text { ISCHEMIC STROKE } \\
+ \text { TIA }\end{array}$ & $\begin{array}{l}\text { ANY EXTRACRANIAL } \\
\text { HEMORRHAGE }\end{array}$ \\
\hline $\begin{array}{l}\text { Coté } \\
(2014)^{30}\end{array}$ & $\begin{array}{l}\text { CLOPIDOGREL+ } \\
\text { ASPIRIN VS ASPIRIN }\end{array}$ & $\begin{array}{l}\text { RDBPC } \\
3.5 \text { YEARS** }\end{array}$ & $\begin{array}{l}838 \\
\text { DAPT: } 427 \\
\text { ASA+P: } 411\end{array}$ & $\begin{array}{l}\text { POST HOC STROKE/ } \\
\text { RECURRENT ISCHEMIC } \\
\text { STROKE }\end{array}$ & $\begin{array}{l}\text { ANY EXTRACRANIAL } \\
\text { HEMORRHAGE }\end{array}$ \\
\hline $\begin{array}{l}\text { COMPRESS } \\
(2016)^{31}\end{array}$ & $\begin{array}{l}\text { CLOPIDROGREL+ } \\
\text { ASPIRIN } \\
\text { VS ASPIRIN + PLACEBO }\end{array}$ & $\begin{array}{l}\text { RDBPC } \\
30 \text { DAYS }\end{array}$ & $\begin{array}{l}334 \\
\text { DAPT: } 167 \\
\text { ASA: } 167\end{array}$ & $\begin{array}{l}\text { STROKE/RECURRENT } \\
\text { ISCHEMIC STROKE }\end{array}$ & $\begin{array}{l}\text { ANY EXTRACRANIAL } \\
\text { HEMORRHAGE }\end{array}$ \\
\hline $\begin{array}{l}\text { POINT } \\
(2018)^{32}\end{array}$ & $\begin{array}{l}\text { CLOPIDOGREL+ } \\
\text { ASPIRIN } \\
\text { VS ASPIRIN + PLACEBO }\end{array}$ & $\begin{array}{l}\text { RDBPC } \\
90 \text { DAYS }\end{array}$ & $\begin{array}{l}4881 \\
\text { DAPT: } 2432 \\
\text { ASA: } 2449\end{array}$ & $\begin{array}{l}\text { COMPOSITE*/ } \\
\text { RECURRENT } \\
\text { ISCHEMIC STROKE }\end{array}$ & $\begin{array}{l}\text { MAJOR } \\
\text { EXTRACRANIAL } \\
\text { HEMORRHAGE }\end{array}$ \\
\hline $\begin{array}{l}\text { CASISP } \\
(2008)^{33}\end{array}$ & $\begin{array}{l}\text { CILOSTAZOL VS } \\
\text { ASPIRIN }\end{array}$ & $\begin{array}{l}\text { RDBPC } \\
12-18 \\
\text { MONTHS }\end{array}$ & $\begin{array}{l}720 \\
\text { CILOSTAZOL: } 360 \\
\text { ASA: } 359\end{array}$ & $\begin{array}{l}\text { RECURRENT ISCHEMIC } \\
\text { STROKE }\end{array}$ & $\begin{array}{l}\text { ANY EXTRACRANIAL } \\
\text { HEMORRAGHE }\end{array}$ \\
\hline $\begin{array}{l}\text { CSPS-2 } \\
(2010)^{34}\end{array}$ & $\begin{array}{l}\text { CILOSTAZOL VS } \\
\text { ASPIRIN }\end{array}$ & $\begin{array}{l}\text { RDBCT } \\
1-5 \text { YEARS }\end{array}$ & $\begin{array}{l}2672 \\
\text { CILOSTAZOL: } 1337 \\
\text { ASA: } 1335\end{array}$ & $\begin{array}{l}\text { NON CARDIOEMBOLIC } \\
\text { STROKE/RECURRENT } \\
\text { ISCHEMIC STROKE } \\
+ \text { TIA }\end{array}$ & $\begin{array}{l}\text { ANY EXTRACRANIAL } \\
\text { HEMORRHAGE }\end{array}$ \\
\hline $\begin{array}{l}\text { PICASSO } \\
(2018)^{35}\end{array}$ & $\begin{array}{l}\text { CILOSTAZOL + } \\
\text { PLACEBO VS ASPIRIN } \\
+ \text { PLACEBO }\end{array}$ & $\begin{array}{l}\text { RDBPCT } \\
5 \text { YEARS }\end{array}$ & $\begin{array}{l}1534 \\
\text { CILOSTAZOL: } 766 \\
\text { ASA }=768\end{array}$ & $\begin{array}{l}\text { COMPOSITE/RECURRENT } \\
\text { ISCHEMIC STROKE }\end{array}$ & $\begin{array}{l}\text { ALL EXTRACRANIAL } \\
\text { HEMORRAGHE }\end{array}$ \\
\hline $\begin{array}{l}\text { CSPS.com } \\
(2019)^{36}\end{array}$ & $\begin{array}{l}\text { CILOSTAZOL + } \\
\text { ASPIRIN VS ASPIRIN } \\
\text { OR CLOPIDOGREL + } \\
\text { ASPIRIN VS ASPIRIN }\end{array}$ & $\begin{array}{l}\text { RCT } \\
\text { 3-5 YEARS }\end{array}$ & $\begin{array}{l}1879 \\
\text { DAPT: } 932 \\
\text { DIPIRIDAMOL + ASA: } \\
947\end{array}$ & $\begin{array}{l}\text { RECURRENT ISCHEMIC } \\
\text { STROKE + TIA }\end{array}$ & $\begin{array}{l}\text { MAJOR } \\
\text { EXTRACRANIAL } \\
\text { HEMORRHAGE }\end{array}$ \\
\hline $\begin{array}{l}\text { SOCRATES } \\
(2017)^{37}\end{array}$ & $\begin{array}{l}\text { TICAGRELOR VS } \\
\text { ASPIRIN }\end{array}$ & $\begin{array}{l}\text { RDBCT } \\
90 \text { DAYS }\end{array}$ & $\begin{array}{l}13199 \\
\text { TICAGRELOR: } 6589 \\
\text { ASA: } 6610\end{array}$ & $\begin{array}{l}\text { COMPOSITE*/ } \\
\text { RECURRENT } \\
\text { ISCHEMIC STROKE } \\
+ \text { TIA }\end{array}$ & $\begin{array}{l}\text { MAJOR } \\
\text { EXTRACRANIAL } \\
\text { HEMORRHAGE }\end{array}$ \\
\hline $\begin{array}{l}\text { ESPRIT } \\
(2006)^{38}\end{array}$ & $\begin{array}{l}\text { DIPYRIDAMOLE + } \\
\text { ASPIRIN VS ASPIRIN }\end{array}$ & $\begin{array}{l}\text { RCT } \\
6 \text { MONTHS }\end{array}$ & $\begin{array}{l}2739 \\
D+A: 1363 \\
\text { ASA: } 1376\end{array}$ & $\begin{array}{l}\text { COMPOSITE*/ } \\
\text { RECURRENT } \\
\text { ISCHEMIC STROKE }\end{array}$ & $\begin{array}{l}\text { MAJOR } \\
\text { EXTRACRANEAL } \\
\text { HEMORRHAGE }\end{array}$ \\
\hline
\end{tabular}

RDBPC: Randomized double-blind placebo controlled, RDBCT: Randomized double-blind controlled trial, RCT: Randomized controlled trial, TIA: Transient ischemic attack, DAPT: Dual antiplatelet therapy, ASA: Aspirin, P: Placebo, D + ASA. *A composite outcome means the sum of death, myocardial infaretion and stroke. *Mean duration. 
as the active control for reducing the risk of events? Of which, two responses can occur: a) HO (null hypothesis): the new treatment is less effective for event reduction (lower) or is more effective (it is higher) and b) H1 (alternative hypothesis): the new treatment is at least as effective as the active control for event reduction (not lower). Adopting the answer HO as true is based on a decision rule according to the statistical significance of the p-value. However, the p-value calculated in non-inferiority tests is special; is ealled "p of non-inferiority" different from the $\mathrm{p}$ of superiority; the difference is in the confidence intervals (IC), if in the 95\% CI range is not included the unit " 1 ", we assume that there is significance for superiority (e.g.: $0.78-0.98$ or 1.08-2.23), but if the opposite is the 95\% CI range the unit " 1 " is included, namely accepted that there is no statistical significance (e.g. 0.72-1.12), and we would be talking about equivalence or non-inferiority between two treatments as long as the confidence interval does not exceed the noninferiority limits. The $\mathrm{H} 1$ alternative hypothesis will be adopted as true, in circumstances where the experimental treatment is not expected to be more effective than the standard treatment or active control, but the new drug offers additional advantages. Such advantages could be a better safety profile, fewer side effects, easier administration, less need for controls and even a lower total cost (39-42). Not inferiority or equivalence are synonyms: according to the CONSORT declaration (43) for randomized controlled studies, non-inferiority generally applies to the predefined upper limit of a single tale $(\mathrm{p}<0.025)$ and equivalence is interpreted when an upper boundary is defined $(\Delta+)$ and a lower boundary $(\Delta-)$, in this case, the analysis is two tales $(\mathrm{p}<0.05)$. However, there is no defined criterion and many authors claim no inferiority or equivalence when the values of the 95\% CI fall within the two predefined limits.

\section{How is the non-inferiority limit calculated?}

This systematic review analyses aspirin as standard treatment or active control ver- sus treatment with other antiplatelet agents in reducing cerebral ischemic thrombotic events (recurrent ischemic stroke and transient ischemic attack), setting limits for non-inferiority or equivalence for antiplatelet agents and aspirin. For the analysis of non-inferiority studies, the upper limit or predefined limit of non-inferiority $(\Delta+)$ for aspirin was set at 1.33 according to Shinohara et al (34) from a meta-analysis published in 2002 (44), in which was estimated the effect of aspirin versus placebo on the prevention of ischemic stroke events with respect to placebo or lack of treatment. In this way, the upper limit of non-inferiority was set at 1.33 and the lower limit of the non-inferiority limits $(\Delta-)$ would be $0.67(1-0.33=$ $0.67)$, everything that exceeds those limits is demonstrable for superiority or non-inferiority is not demonstrated.

\section{Statistical analysis. Meta-analysis description}

The guidelines developed according to the recommendations of the PRISMA method (45) were followed. The statements for non-inferiority studies were applied according guidelines of the CONSORT group (43). The selected studies conducted direct comparisons between antiplatelet drugs and aspirin on a primary analysis of effectiveness and safety events. The meta-analysis was developed under the graphical presentation type "Forest plot" with the random effect modality and the relative risk ( $R R$ as an effect measure, although estimates may vary slightly from published hazard ratios for individual trials as hazard ratios use failure-time data, vs. event-no event data for RR) with the following components: 1 . Study name, 2. Antiplatelet, events/total of patients (\%), 3. Aspirin, events/total patients (\%), 4. Number Needed to Treat (NNT) for effectiveness and the Number Needed to Harm (NNH) for safety or adverse effect, calculated as the inverse of the absolute risk reduction or increase, 5. Percentage of relative weight of each study and 6. RR (IC95\%) and p of each

Vol. 61(3): 265 - 282, 2020 
study. Statistical meta-analysis was carried out with the Comprehensive Meta-Analysis programme (Biostat, Englewood, NJ). As statistical parameters, the consistence for heterogeneity $\left(\mathrm{I}^{2}\right)$ was determined as low $(<25 \%)$, moderate $(25 \%$ to $75 \%)$ and high $(>75 \%)$ by testing the $\mathrm{chi}^{2}$ calculation of each meta-analysis (cochrane Q) according to the Higgins formula (46), calculation of $Z$ value and $\mathrm{p}<0.05$ for statistical significance. The terms clinical and statistical significance refer to reduction or increased risk of events with a significant result or not, for example, there may be the case of clinical significance with reduction or increase of events without statistical siǵnificance [Vizcaíno G. 2020, book Evidence Based Medicine and analysis of clinical research designs, $2^{\text {nd }}$ edition, in press (Spanish)].

\section{RESULTS}

A systematic review was conducted with meta-analysis on recurrent ischemic stroke and transient ischemic attack of 12 randomized controlled studies with 52204 patients, the main characteristic was to observe whether there was correspondence with criteria of noninferiority using aspirin as an active control. For this purpose, they were classified for effectiveness and safety analysis in three groups, the first consisting of the 12 selected studies (antiplatelet drugs vs aspirin alone), the second, those studies that used dual therapy (clopidogrel-aspitin vs aspirin alone) and the third group, the studies describing the effect of cilostazol versus aspirin as active control.

\section{Antiplatelet versus aspirin therapy}

In this meta-analysis on effectiveness and safety was performed based on the combined analysis of 12 studies with different antiplatelet treatments versus aspirin as active control. Fig. 2 shows the effect of the different treatments on the reduction of recurrent ischemic stroke events. With the exception of the COMPRESS study, all studies revealed clinical reduction of ischemic events and 50\% of them obtained statistical significance. The combined result showed clinical and significant reduction in the risk of recurrent ischemic stroke of $22 \%$ [RR $(95 \% \mathrm{CI})=0.78(0.72-0.84), \mathrm{p}<0.0001]$, the absolute risk reduction was $1.5 \%$, the NNT was 67 and studies were consistent for low hetero-

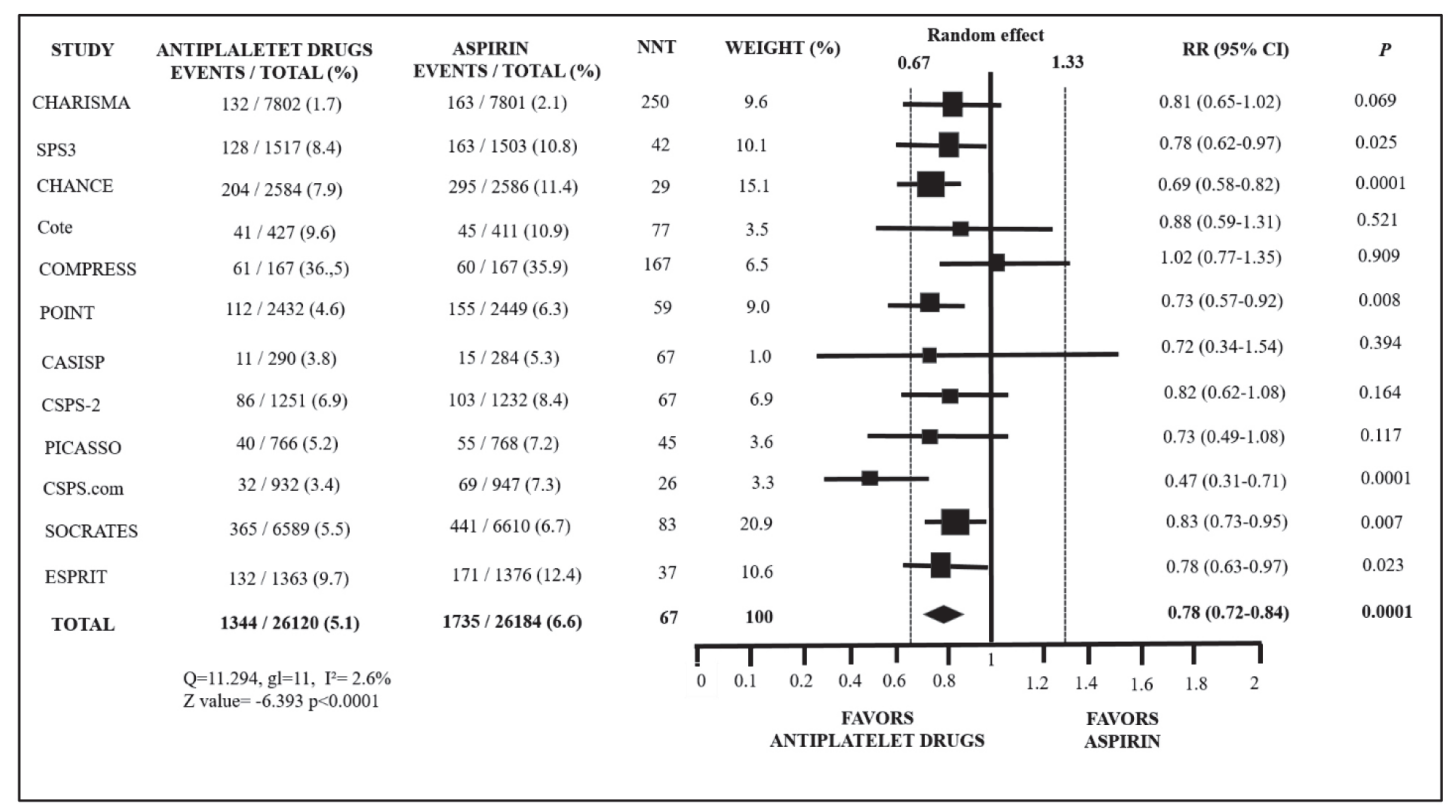

Fig. 2. Meta-analysis of effectiveness in studies with different antiplatelet aǵents versus aspirin as active control. 
geneity $\left(\mathrm{I}^{2}=2.6 \%\right)$. Non-inferiority could not be demonstrated, although equivalence might be surrogate it (the composite of the studies lies between the limits of non-inferiority), superiority of antiplatelet over aspirin can be claimed in terms of effectiveness.

The safety meta-analysis (Fig. 3) between antiplatelet studies versus aspirin as an active control showed individually in some studies increased hemorrhagic risk and in others revealed otherwise, manifesting in the result combined as a slight clinical increase but nonsignificant risk (2\%) with antiplatelet drugs [RR (95\% CI) $=1.02$ (0.74-1.41), $\mathrm{p}=0.899]$. The absolute risk increase was $0.2 \%$, the $\mathrm{NNH}$ was 500 and the consistency of studies revealed low heterogeneity $\left(\mathrm{I}^{2}=8.8 \%\right)$.

\section{Clopidogrel versus aspirin}

The effect of dual therapy (clopidogrel + aspirin) versus aspirin alone on the reduction of recurrent ischemic stroke events is shown in Fig. 4. It was observed that individually any study did not met criteria for non-inferiority. Studies SPS3, CHANCE 2013 and POINT demonstrated clinical and significant risk reduction. The combined result indicates also a $22 \%$ clinical and significant reduction in ischemic stroke recurrence in favor of dual therapy [RRI $(95 \%$ CI $)=0.78(0.70-0.87), \mathrm{p}<0.0001)$ so it was assumed that dual therapy treatment is equivalent when compared to aspirin (does not exceed lower limits), however, in this case, superiority can be claimed. The absolute risk reduction was $1.4 \%$, the NNT was 71 and $\mathrm{I}^{2}=$ $0 \%$ (evidence of homogeneity).

Safety analysis (Fiǵ. 5) regarding extracranial haemorrhagic manifestations comparing dual therapy (clopidogrel + aspirin) versus aspirin alone reveals that all studies, showed increased hemorrhagic risk for dual therapy. The combined result exhibit a clinical and significant increase in bleeding of $58 \%$ with the use of DAPT [RR $(95 \%$ CI $)=$ $1.58(1.30-1.93) \mathrm{p}<0.0001)]$. The absolute risk increase was $0.9 \%, \mathrm{NNH}=111$ and the consistency of the study showed homogeneity among all studies $\left(\mathrm{I}^{2}=0 \%\right)$.

\section{Cilostazol versus Aspirin}

Analysis on the effectiveness evidence, with the exception of the CSPS.com study, all studies revealed a non-significant risk reduction (Fig. 6), but none of them met

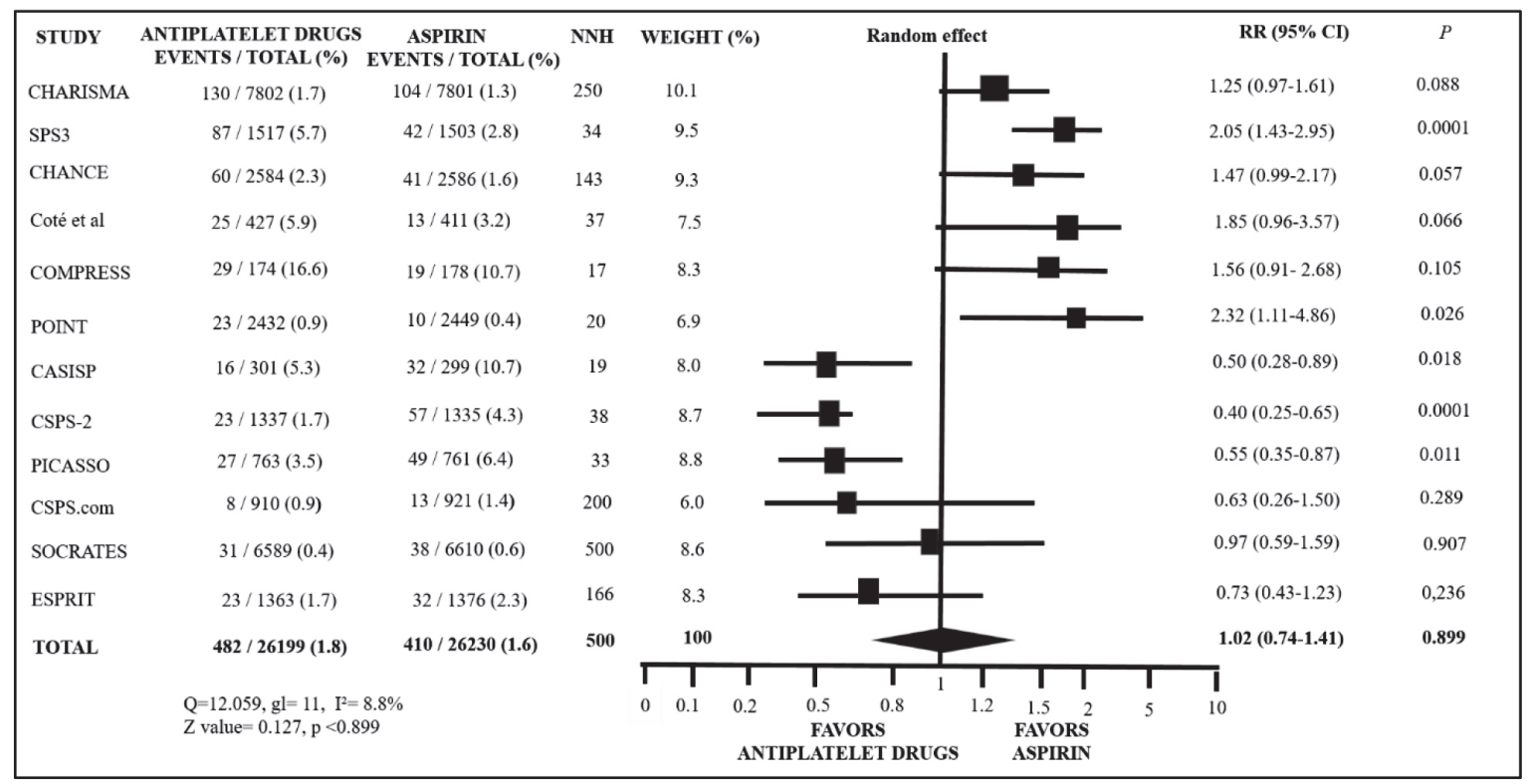

Fig. 3. Security meta-analysis. Effect of antiplatelet treatment versus aspirin as active control.

Vol. 61(3): 265 - 282, 2020 


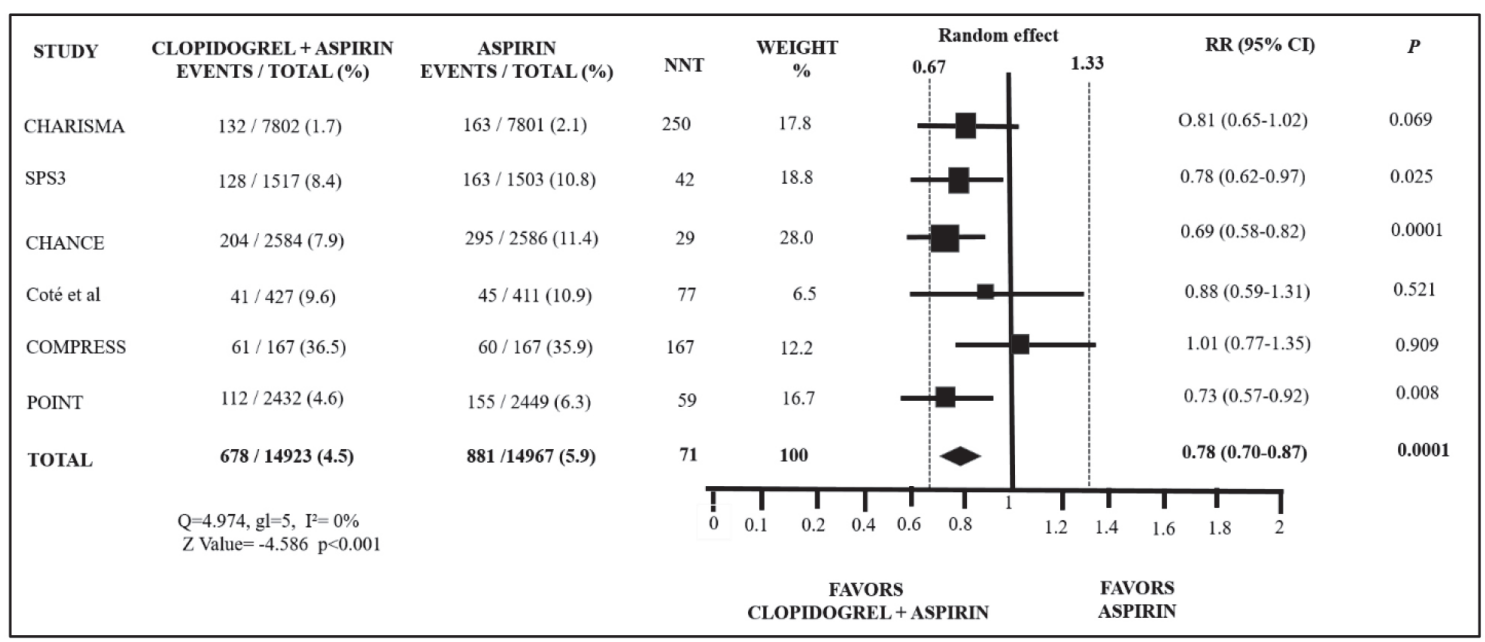

Fig. 4. Meta-analysis of effectiveness with dual therapy (clopidogrel + aspirin) versus aspirin alone.

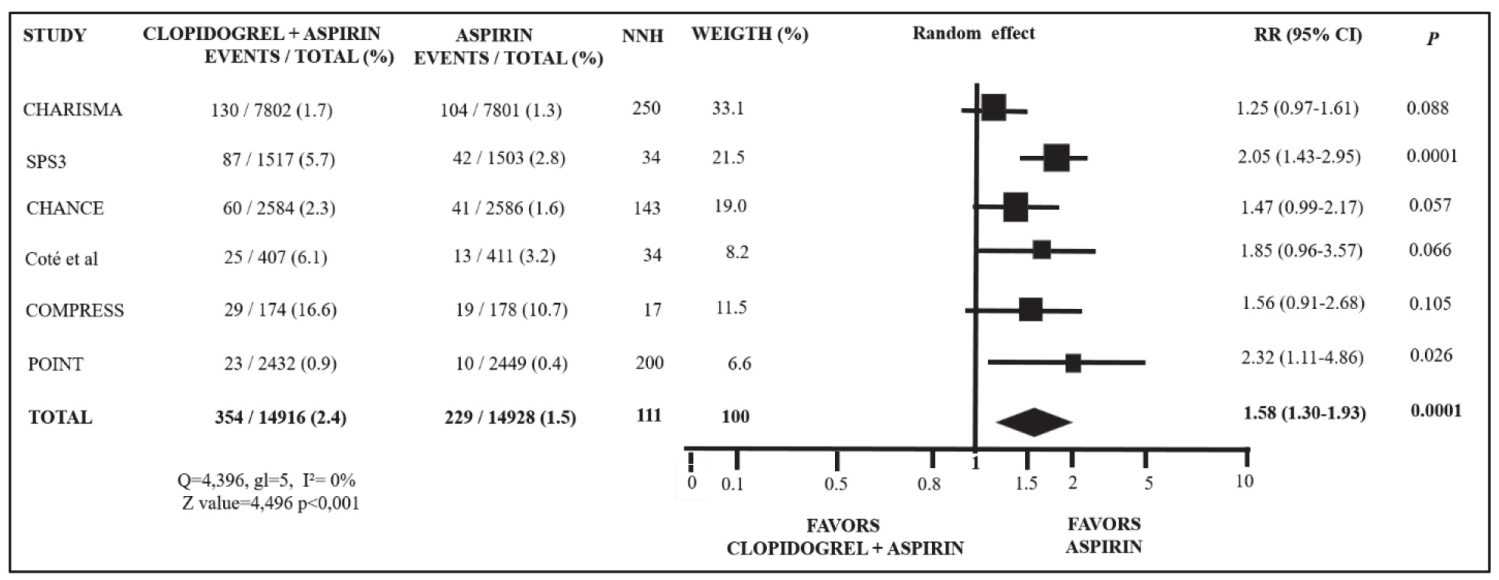

Fig. 5. Security meta-analysis between dual therapy (clopidogrel + aspirin) versus aspirin alone.

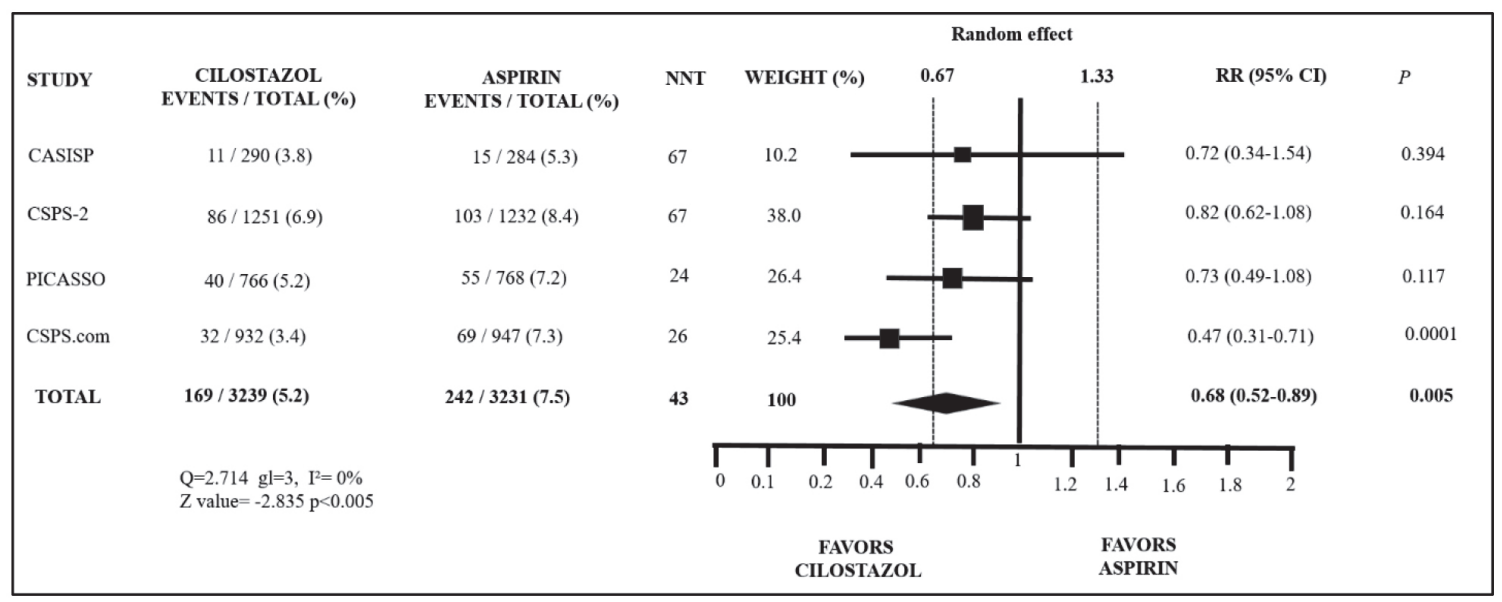

Fig. 6. Meta-analysis of effectiveness among cilostazol versus aspirin. 
non-inferiority criteria with aspirin as active control. The combined result shows a clinical and significant reduction in favor of cilostazol in recurrent stroke of 32\% [RR (95\% CI) $=0.68(0.52-0.89), \mathrm{p}<0.005)]$ so that cilostazol superiority over aspirin can be observed. The absolute risk reduction was $2.3 \%$, the $\mathrm{NNT}=43$ and there was homogeneity between studies $\left(\mathrm{I}^{2}=0 \%\right)$.

The safety analysis of the presence of extracranial bleeding events in recurrent ischemic stroke determined that cilostazol revealed a reduction in bleeding events in all studies compared to aspirin (Fig. 7). The combined result shows a clinical and significant reduction of $52 \%$ [RR $(95 \% \mathrm{CI})=0.48$ (0.37-0.63), p<0.005] for the risk of bleeding favoring treatment with cilostazol. The absolute risk reduction was $2.4 \%$, the $\mathrm{NNH}$ was 42 and studies were consistent in demonstrating homogeneity $\left(\mathrm{I}^{2}=0 \%\right)$.

\section{DISCUSSION}

The present systematic review, revealed a superiority (22\%, absolute risk reduction $1.4 \%)$ in the reduction of events of recurrent ischemic stroke with any antiplatelet treatment modality against aspirin alone. Non-inferiority or equivalence was observed between antiplatelet drugs and aspirin alone although superiority can be claimed. The se- curity analysis demonstrated two groups of results, one with increased bleeding risk and other group on the contrary, showed no differences in the global result. A clinical and significant risk reduction (22\%, absolute risk reduction $1.4 \%$ ) about the recurrence of ischemic ictus was observed in the group of DAPT (clopidogrel-aspirin) against aspirin alone but with a significant 58\% higher risk of bleeding (absolute risk increment $0.9 \%$ ). The group of studies with cilostazol vs aspirin showed a superiority in the risk reduction of recurrent ischemic events with cilostazol and also, in the bleeding events against aspirin $(32 \%$ and $52 \%$ respectively, absolute risk reduction $2.3 \%$ and $2.4 \%$ respectively). On the other hand, the studies with ticagrelor and dipyridamole-aspirin versus aspirin alone paper exhibited a clinical but not quite significant lower risk reduction in the recurrence of ischemic ictus but no evidence of differences in the bleeding risk was observed.

The pharmacological use of aspirin on the prevention of recurrent ischemic stroke and TIA, was analyzed in other 12 randomized studies finding a reduction of $54 \%$ in events with the use of aspirin at 12 weeks in relation to control and $74 \%$ reduction in disability or fatal ischemic stroke (47). In systematic reviews related to the use of DAPT (clopidogrel + aspirin) versus aspirin

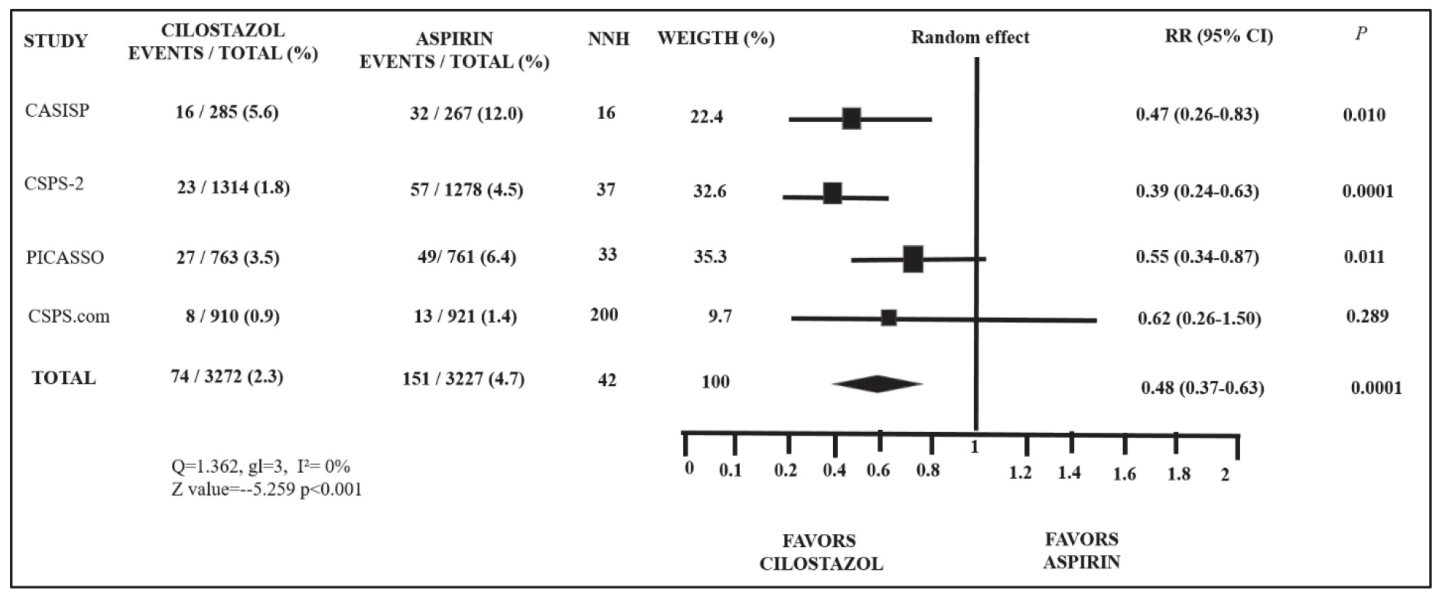

Fig. 7. Security meta-analysis between cilostazol versus aspirin. 
alone (48), there was a $27 \%$ of significant risk reduction for dual therapy in fatal and non-fatal ischemic stroke (RR 0.73; 95\% CI: 0.59-0.91; participants 4006; studies 5; moderate quality evidence). However, the risk of higher bleeding was attributed to the group with dual therapy (RR 1.44, CI 95\%: 1.25-1.64; participants 33300; studies 10 ; evidence of moderate quality). It is also mentioned similar findings published by Palacio et al. (49) with the present systematic review, with DAPT vs aspirin alone, they found that DAPT reduced ischemic stroke by $23 \%$ (odds ratio $=0.77 ; 95 \%$ CI: $0 \cdot 70-0 \cdot 85)$ and the risk of major bleeding was increased by $40 \%$ (odds ratio $=1 \cdot 40,95 \%$ CI: $1 \cdot 26-1 \cdot 55)$ by dual antiplatelet therapy. Patients who have presented acute minor ischemic stroke or TIA receiving DAPT could have a better prognostic if this modality is discontinued between 10 to 21 days after the initiation of therapy (50).

Published data on the use of tienopiridines versus aspirin found a significant reduction in ischemic events favorable to the tienopiridines group [622/ 11355 (5.5\%) versus $704 / 11423$ (6.2\%), OR 0.89; 95\% CI: $0.79-0.99)]$; in relation to the extracranial major hemorrhage, the data showed no significant difference between the two groups [(100/ 9753 (1.03\% vs $102 / 9752$ (1.05\%); OR: 0.98, 95\% CI: 0.74-1.29)] (51). Moreover, a systematic review of recurrent ischemic stroke with data collected from seven clinical trials (41042 participants) reported that the use of antiplatelets (mainly aspirin) was associated with a significant reduction in recurrent ischemic stroke [ (OR 0.77; 95\% CI: 0.69-0.87; p <0.00001), NNT 140] (12).

One of the most important questions regarding treatment is when to start antiplatelet treatment. In patients at high risk of recurrent stroke, a recent clinical practice guide about the use of DAPT (clopidogrel + aspirin) versus aspirin monotherapy (6), the patient was classified as high risk (ABCD2 scale >4) after an AIS (acute ischemic stroke) or a minor ischemic stroke without neurological deficit (NIHSS scale <3) and sets to start with dual therapy as soon as possible after the ischemic event (high evidence quality, strong degree of recommendation) for 10 to 21 days and then continue indefinitely with a single antiplatelet agent (6).

In relation to lacunar ischemic stroke, a systematic review found that any antiplatelet treatment against placebo after an ischemic stroke reduces the frequency of stroke recurrence in general (absolute risk reduction: 3.5\%; NNT: 29) and ischemic stroke (absolute risk reduction: 5.9\%; NNT: 17) (52).

Treatment with cilostazol (phosphodiesterase inhibitor-3) has been used because it offers in addition to its antiplatelet function, protection of the vascular endothelium and arteriolar vasodilation (53).

Another aspect to consider is the presence of resistance to aspirin or clopidogrel in patients with vascular brain disease, when this occurs, the prognosis of recurrence increases (54). Platelet functionalism identifies "non-responders" through platelet aggregation with arachydonate $(\geq 20 \%$ with $0.5 \mathrm{mg} / \mathrm{mL})$ and $\mathrm{ADP}(\geq 70 \%$ with $5-\mathrm{mol} / \mathrm{L})$ for aspirin and clopidogrel when aggregation is greater than $40 \%$ with $5-\mathrm{mmol} / \mathrm{L}$ for ADP. It was found a study of 324 patients with ischemic stroke $43 \%$ and $35 \%$ of non-responders for aspirin and clopidogrel respectively (55). In these cases, increased doses of aspirin or the addition of another antiplatelet agent may reduce recurrence of ischemic events $(56,57)$. Lee et al. (58) reported a $30 \%$ reduction in the risk of ischemic stroke in non-responders to aspirin when clopidogrel or ticagrelor was added. In another study the effectiveness between prasugrel and clopidogrel was compared with a reduction in the risk of stroke after an acute coronary accident, presumably the most powerful and lasting effect of prasugrel favors this reduction (59).

This systematic review has several limitations. The effectiveness analysis in the different studies was determined only for recurrent ischemic stroke and transient ischemic 
attack as the primary end point, when the study showed a composite outcome (death, myocardial infaretion and stroke) only data for ischemic stroke and transient ischemic attack were extracted. Patients with moderate-to-severe stroke, those with cardioembolic stroke, and those who were candidates for thrombolysis or thrombectomy were not studied in this systematic review. No secondary efficacy events were analyzed. When seemingly duplicate studies were analyzed, the initial study was chosen, for example, the CHANCE study has several publications in different journals and in different years apparently with the same number of cases and equal number of events $(29,60,61)$.

To unify the measure of effect in metaanalysis, relative risk (RR) was chosen, even though some studies have reported it as a measure of hazard ratio, odds ratio or percentage difference. On the other hand, the safety analysis mainly studied major bleeding events, although some studies included total data because they only reported bleeding events without discrimination of the grade of severity, knowing that in this case it might be evidence of confusion. No data on hemorrhagic stroke were analyzed, because the main adverse effect of antiplatelet treatment is bleeding and with this specific outcome the data on major extracranial bleeding could not be reliably estimated. On the other hand, in some of the articles analyzed here, there was an important reduction of hemorrhagic ictus with clopidogrel and cilostazol versus aspirin alone $(32,35)$.

In some studies, there was a multiple scheme of treatment against aspirin, for example the CSPS.com study (36) used clopidogrel-aspirin and cilostazol-aspirin, so for comparison the last modality of treatment was chosen. For the PICASSO study (35), probucol a lipid lowering drug was added to cilostazol or aspirin and despite the safety outcome was hemorrhagic ictus, only data for ischemic stroke was extracted from the composite primary outcome. There were marked differences between the studies re- lated to the duration of them; therefore, the results of meta-analysis should be carefully analyzed when comparing short-term studies with longer ones.

In conclusion, a long-term treatment with aspirin monotherapy is recommended in some systematic reviews $(12,62)$ for a minor ischemic stroke event or small vessel disease presented as lacunar stroke or TIA; and as one the alternatives, is clopidogrel (as dual therapy) with a reduction of ischemic stroke of $25 \%$, when installed for a short time $(<1$ month of the primary event occurred) and lower risk of bleeding compared to longterm therapy (63). Other systematic reviews also point out to the increased effect of dual therapy (28\% reduction in the risk of ischemic stroke recurrence), but with moderate to severe bleeding events showed an increase of $64 \%$ (64). Cilostazol has been proven efficacy and safety against aspirin, so it could be another alternative. Other combinations were also referred in a systematic review that analyzed dual therapy with aspirin plus dipyridamole (65) or aspirin with prasugrel or ticagrelor (66), with outcomes favoring dual therapy versus monotherapy; but the hemorrhagic risk, although not significant, is increased with the combination of antiplatelets drugs. It is recommended before deciding treatment to avoid recurrence, to determine the origin or cause conditioning the stroke, identifying it dependence about others factors (e.g. high blood pressure) and stratification of the patient's risk. This systematic review evidences that, although in some instances non-inferiority could not be demonstrated, a clinical non-significant risk reduction in recurrent ischemic stroke was observed in the majority of any antiplatelet versus aspirin alone; and that the combined result can be expressed as superiority over aspirin alone on the risk reduction in the recurrence of minor ischemic stroke. With the sole exception of cilostazol trials, there was an increase of the bleeding risk when the antiplatelet drugs regimens were compared with aspirin alone. 


\section{ACKNOWLEDGMENTS}

To Dr. María Diez-Ewald for her careful work in the revision and style of this article.

\section{REFERENCES}

1. Jauch EC, Saver JL, Adams HP, Bruno A, Connors JJ, Demaerschalk BM, American Heart Association Stroke Council, Council on Cardiovascular Nursing, Council on Peripheral Vascular Disease, Council on Clinical Cardiology. Guidelines for the early management of patients with acute ischemic stroke: a guideline for healtheare professionals from the American Heart Association/American Stroke Association. Stroke 2013;44:870-947. DOI: 10.1161/ STR.0b013e318284056a.

2. Zerna C, Thomalla G, Campbell B C V, Rha JH, Hill MD. Current practice and future directions in the diagnosis and acute treatment of ischaemic stroke. Lancet 2018;392:1247-1256. DOI: 10.1016/ s0140-6736(18)31874-9.

3. Broderick JP, Adeoye O, Elm J. Evolution of the Modified Rankin Seale and its use in future stroke trials. Stroke 2017;48:2007-2012. DOI: 10.1161/STROKEAHA.117.017866.

4. Dufouil G, Beiser A, McLure LA, Wolf PA, Tzourio C, Howard VJ, Westwood AJ, Himali JJ, Sullivan L, Aparicio HJ, KellyHayes M, Ritehie K, Kase CS, Pikula A, Romero JR, D'Agostino RB, Samieri C, Vasan RS, Chêne G, Howard G, Seshadri S. Revised Framingham Stroke Risk Profile to reflect temporal trends. Circulation. 2017;135(12):1145-1159.

5. Powers WJ, Rabinstein AA, Ackerson T, Adeoye OM, Bambakidis NC, Becker K. on behalf of the American Heart Association Stroke Council. 2018 Guidelines for the rarly management of patients with aute ischemic stroke. Stroke 2018;49:e46-e99. DOI: 10.1161/STR.0000000000000158.

6. Prasad K, Siemieniuk R, Hao Q, Guyatt G, O'Donnell M, Lytvyn L, Heen AF, Agoritsas T, Vandvik PO, Gorthi SP, Fisch L, Jusufovic $\mathrm{M}$, Muller J, Booth $\mathrm{B}$, Horton $\mathrm{E}$, Fraiz A, Siemieniuk J, Fobuzi AC, Katragunta N, Rochwerg B. Dual antiplatelet therapy with aspirin and clopidogrel for acute high risk transient ischaemic attack and minor ischaemic stroke: a clinical practice guideline. BMJ 2018;363: k5130. DOI:10.1136/ bmj.k5130.

7. Mayer L, Ferrari J, Krebs S, Boehme C, Toell T, Matosevic B, Tinchon A, Brainin M, Gattringer T, Sommer P, Thun P, Willeit J, Lang W, Kiechl S, Knoflach M, Austrian Stroke Unit Collaborators. ABCD3I Score and the risk of early or 3-month stroke recurrence in tissue- and time-based definitions of TIA and minor sroke. J Neurol 2018;265 (3):530-534. DOI: 10.1007/ s00415-017-8720-8.

8. Odier C, Michel P. Common stroke syndromes. Textbook of stroke medicine. Brainin M, Heiss WD eds. Cambridge University Press 2019, pp: 169-181. DOI: 10. 1017/9781108659574.

9. Kapil N, Datta YH, Alakbarova N, Bershad E, Selim M, Liebeskind DS, Divani AA. Antiplatelet and anticoagulant therapies for prevention of ischemic stroke. Clin Appl Thromb Hemost 2016;23(4):301-318. DOI: $10.1177 / 1076029616660762$.

10. The International Stroke Trial (IST): A randomised trial of aspirin, subcutaneous heparin, both, or neither among 19435 patients with acute ischaemic stroke: International Stroke Trial Collaborative Group. Lancet 1997;349:1569-1581.

11. Chinese Acute Stroke Trial, CAST Collaborative Group. Randomised placebo-controlled trial of early aspirin use in 20,000 patients with acute ischaemic stroke: Lancet 1997;349:1641-1649.

12. Sandercock PA, Counsell C, Tseng MC, Ceconi E. Oral antiplatelet therapy for acute ischaemic stroke. Cochrane Database Syst Rev. 2014: Https://doi. org /10.1002/14651858.CD000029.

13. Campuzano Maya G. Inhibidores del receptor plaquetario P2Y12. Parte 1 de 2: eseenario de acción, farmacología, aplicación clínica y limitaciones de su uso. Med Lab 2017;23:13-44.

14. Gresele P, Momi S, Falcinelli E. Anti-platelet therapy: phosphodiesterase inhibitors. Br J Clin Pharmacol 2011;72:634-646.

15. Yamamoto $H$, Takahashi $K$, Watanabe $H$, Yoshikawa Y, Shirakawa R, Higashi T, Kawato M, Ikeda T, Tabuchi A, Morimoto 
T, Kita T, Horiuchi H. Evaluation of the antiplatelet effects of cilostazol, a phosphodiesterase 3 inhibitor, by VASP phosphorylation and platelet aǵgregation. Cire J 2008;72:1844-1851.

16. Siebler M, Hennerici MG, Schneider D, von Reutern GM, Seitz RJ, Röther J, Witte OW, Hamann G, Junghans U, Villringer A, Fiebach JB. Safety of tirofiban in acute ischemic stroke: the SaTIS trial. Stroke 2011;42:2388-2392. DOI: 10.1161/STRO KEAHA.110.599662.

17. Pancioli AM, Broderick J, Brott T, Tomsick T, Khoury J, Bean J, del Zoppo G, Kleindorfer D, Woo D, Khatri P, Castaldo J, Frey J, Gebel J Jr, Kasner S, Kidwell C, Kwiatkowski T, Libman R, Mackenzie R, Scott P, Starkman S, Thurman RJ; for the CLEAR Trial Investigators. The combined approach to lysis utilizing eptifibatide and rt-PA in acute ischemic stroke: the CLEAR stroke trial. Stroke 2008;39:3268-3276. DOI: 10.1161/STROKEAHA.108.517656.

18. Adeoye O, Sucharew H, Khoury J, Tomsick T, Khatri P, Palesch Y, Schmit PA, Pancioli AM, Broderick JP; for the CLEAR-ER, IMS III, and ALIAS Part 2 Investigators. Recombinant tissue-type plasminogen activator plus eptifibatide versus recombinant tissue-type plasminogen activator alonein acute ischemic stroke: propensity score-matehed post hoc analysis. Stroke 2015;46:461-464. DOI: 10.1161/ STROKEAHA.114.006743.

19. Adeoye $O$, Sucharew $H$, Khoury J, Vagal A, Schmit PA, Ewing I, Levine SR, Demel S, Eckerle B, Katz B, Kleindorfer D, Stettler B, Woo D, Khatri P, Broderick JP, Pancioli AM. Combined approach to lysis utilizing eptifibatide and recombinant tissue-type plasminogen activator in acute ischemic stroke-full dose regimen stroke trial. Stroke 2015;46:2529-2533. DOI: 10.1161/STRO KEAHA.115.010260.

20. Ciccone A, Motto C, Abraha I, Cozzolino F, Santilli I. Glycoprotein IIb-IIIa inhibitors for acute ischaemic stroke. Cochrane Database Syst Rev 2014:CD005208.

21. Adams HP Jr, Effron MB, Torner J, Dávalos A, Frayne J, Teal P, Leclere J, Oemar B, Padgett L, Barnathan ES, Hacke W; for the AbESTT-II Investigators. Emergency administration of abciximab for treatment of patients with acute ischemic stroke: results of an international phase III trial: Abciximab in Emergency Treatment of Stroke Trial (AbESTT-II). Stroke 2008;39:87-99. DOI: 10.1161/STROKEAHA.106.476648.

22. Bath PM, Woodhouse LJ, Appleton JP, Beridze M, Christensen H, Dineen RA, Flaherty K, Duley L, England TJ, Havard D, Heptinstall S, James M, Kasonde C, Krishnan K, Markus HS, Montgomery AA, Pocock S, Randall M, Ranta A, Robinson TG, Scutt P, Venables GS, Sprigg N. Triple versus guideline antiplatelet therapy to prevent recurrence after acute ischaemic stroke or transient ischaemic attack: the TARDIS RCT. Health Technol Assess 2018;22(48):1-76. DOI: $10.3310 /$ hta22480.

23. Jadad AR, Moore RA, Carroll D, et al. Assessing the quality of reports of randomized clinical trials: ¿is blinding necessary? Control Clin Trials1996;17:1-12.

24. Higgins JPT, Altman DG, Gøtzsche PC, Jüni P, Moher D, Oxman AD, Savovic J, Schulz KF, Weeks L, Sterne JA. The Cochrane Collaboration's tool for assessing risk of bias in randomised trials. BMJ 2011;343:d5928. DOI: 10.1136/bmj.d5928.

25. GUSTO Investigators. An international randomized trial comparing four thrombolytic strategies for acute myocardial infaretion. N Engl J Med 1993;329:67382.

26. Wallentin L, Becker RC, Budaj A, Cannon CP, Emanuelsson H, Held C, Horrow J, Husted S, James S, Katus H, Mahaffey KW, Scirica BM, Skene A, Steg PG, Storey RF, Harrington RA, for the PLATO Investigators. Ticagrelor versus clopidogrel in patients with acute coronary syndromes. N Enǵ1 J Med 2009;361:1045-1057.

27. Bhatt DL, Fox KAA, Hacke W, Berger PB, Black HR, Boden WE, Cacoub P, Cohen EA, Creager MA, Easton JD, Flather MD, Haffner SM, for the CHARISMA Investigators. Clopidogrel and aspirin versus aspirin alone for the prevention of atherothrombotic events. N Enǵl J Med 2006;354:17061717. DOI: 10.1056/NEJMoa060989.

28. The SPS3 Investigators. Effects of Clopidogrel added to aspirin in patients with recent lacunar stroke. N Eng1 J Med 2012;367: 817-825. DOI: 10.1056/NEJMoa1204133. 
29. Wang $Y$, Wang $Y$, Zhao $X$, Liu L, Wang $D$, Wang $\mathrm{C}$, Wang $\mathrm{C}$, Li $\mathrm{H}$, Meng $\mathrm{X}$, Cui L, Jia J, Dong Q, Xu A, Zeng J, Li Y, Wang Z, Xia H, Johnston SC, for the CHANCE Investigators. Clopidogrel with aspirin in acute minor stroke or transient ischemic attack. N Enǵl J Med 2013; 369:11-19. DOI: 10.1056/NEJMoa1215340.

30. Côté R, Zhang Y, Hart RG, McClure LA, Anderson DC, Talbert RL, Benavente OR. ASA failure. Does the combination ASA/ clopidogrel confer better long-term vascular protection? Neurology 2014;82:382389.

31. Hong KS, Lee SH, Kim EG, Cho KH, Chang DI, Rha JH, Bae HJ, Lee KB, Kim DE, Park JM, Kim HY, Cha JK, Yu KH, Lee YS, Lee SJ, Choi JC, Cho YJ, Kwon SU, Kim GM, Sohn SI, Park KY, Kang DW, Sohn CH, Lee J, Yoon BW; COMPRESS Investigators. Recurrent ischemic lesions after acute atherothrombotic stroke clopidogrel plus aspirin versus aspirin alone. Stroke 2016;47:2323-2330. DOI: 10.1161/ STROKEAHA.115.01229.

32. Johnston SC, Easton D, Farrant M, Barsan W, Conwit RA, Elm JJ, Kim AS, Lindblad AS, Palesch YY, The POINT Investigators. Clopidogrel and aspirin in acute ischemic stroke and high-risk TIA. N Engl J Med 2018; 379(3): 215-225. DOI: 10.1056/ NEJMoa1800410.

33. Huang Y, Cheng Y, Wu J, Li Y, Xu E, Hong $Z$, Li Z, Zhang W, Ding M, Gao X, Fan D, Zeng $\mathrm{J}$, Wong $\mathrm{K}$, Lu C, Xiao J, Yao $\mathrm{C}$, on behalf of the cilostazol versus aspirin for secondary Ischaemic stroke prevention (CASISP) cooperation investigators. Cilostazol as an alternative to aspirin after ischaemic stroke: a randomised, double-blind, pilot study. Lancet Neurol 2008; 7:494-499. DOI: 10.1016/S1474-4422(08)70094-2.

34. Shinohara Y, Katayama Y, Uchiyama S, Yamaguchi T, Handa S, Matsuoka K, Ohashi Y, Tanahashi N, Yamamoto H, Genka C, Kitagawa Y, Kusuoka H, Nishimaru K, Tsushima M, Koretsune Y, Sawada T, Hamada $\mathrm{C}$, for the CSPS 2 group. Cilostazol for prevention of secondary stroke (CSPS-2): an aspirin-controlled, double-blind, randomized non-inferiority trial. Lancet Neu- rol 2010;9:959-968 DOI: 10.1016/S14 744422(10)70198-8.

35. Kim BJ, Lee EJ, Kwon SU, Park JH, Kim YJ, Hong KS, Wong LKS, Yu S, Hwang YH, Lee JS, Lee J, Rha JH, Heo SH, Ahn SH, Seo WK, Park JM, Lee JH, Kwon JH, Sohn SI, Jung JM, Navarro JC, Kang DW; PICASSO investigators. Prevention of cardiovascular events in Asian patients with ischaemic stroke at high risk of cerebral haemorrhage (PICASSO): a multicentre, randomised controlled trial. Lancet Neurol 2018;17:509-518. DOI: $10.1016 / S 1474$ 4422(18)30128-5.

36. Toyoda $K$, Uchiyama $S$, Yamaǵuchi $T$, Easton JD, Kimura K, Hoshino H, Sakai N, Okada Y, Tanaka K, Origasa HO, Naritomi $\mathrm{H}$, Houkin K, Yamaguchi K, Isobe M, Minematsu K; CSPS.com Trial Investigators. Dual antiplatelet therapy using cilostazol for secondary prevention in patients with high-risk ischaemic stroke in Japan: a multicenter, open-label, randomized controlled trial. Lancet Neurol 2019;18(6):539-548. DOI: $10.1016 /$ S1474-4422(19)30148-6.

37. Johnston SC, Amarenco P, Albers GW, Denison H, Easton JD, Evans SR, Held P, Jonasson J, Minematsu K, Molina CA, Wang Y, Wong KSL, for the SOCRATES Steering Committee and Investigator. Ticagrelor versus aspirin in acute stroke or transient ischemic attack. $\mathrm{N}$ Enǵl $\mathrm{J}$ Med 2016;375:35-43. DOI: 10.1056/NEJMoa1603060.

38. The ESPRIT Study Group. Aspirin plus dipyridamole versus aspirin alone after cerebral ischaemia of arterial origin (ESPRIT): randomized controlled trial. Laneet 2006;367(9523):1665-1673. DOI: 10. 1016/s0140-6736(06)68734-5.

39. Ferreira-González I. Bases para la interpretación de los estudios de no inferioridad: a propósito de los estudios ROCKETAF, RE-LY y ARISTOTLE. Rev Esp Cardiol 2014;67(6):432-435.

40. Vizcaíno G. La Estadística al alcance del Médico. Análisis crítico de ensayos clínicos. Capítulo III. Los estudios de no inferioridad en clínica médica. Ediciones Astro Data, ISBN 978-980-402-254-5, Maracaibo, pp 153. 
41. Hung HM, Wang SJ, Tsong Y, Lawrence J, O'neil RT. Some fundamental issues with non-inferiority testing in active controlled trials. Stat Med 2003;22:213-225.

42. Pluchino S. Estudios clínicos de no inferioridad y de equivalencia: metodología, análisis e interpretación de los resultados. Avances Cardiol 2009; 29:76-81.

43. Piaǵgio G, Elbourne DR, Altman DG, Pocock SJ, Evans SJW, CONSORT Group. Reporting of noninferiority and equivalence randomized trials. An extension of the CONSORT Statement. JAMA 2006; 295(10):1152-1160. DOI: 10.1001/jama. 295.10.1152.

44. Antithrombotic Trialists Collaboration. Collaborative meta-analysis of randomised trials of antiplatelet therapy for prevention of death, myocardial infaretion, and stroke in high risk patients. BMJ 2002;324(7329):71-86.

45. Moher D, Liberati A, Tetzlaff J, Altman DG; PRISMA Group. Preferred reporting items for systematic reviews and metaanalyses: the PRISMA statement. PLoS Med 2009;6(7): e1000097. DOI: 10.1371/journal.pmed.1000097.

46. Hig̉gins JPT, Thompson SG, Deeks JJ, Altman DG. Measuring inconsistency in metaanalyses. BMJ 2003;327:557-560.

47. Rothwell PM, Algra A, Chen Z, Diener HC, Norrving B, Mehta $Z$. Effects of aspirin on risk and severity of early recurrent stroke after transient ischaemic attack and ischaemic stroke:time-course analysis of randomised trials. Lancet 2016; 388: 365-375. DOI: 10.1016/S0140-6736(16)30468-8.

48. Squizzato A, Bellesini M, Takeda A, Middeldorp S, Donadini MP. Clopidoǵrel plus aspirin versus aspirin alone for preventing cardiovascular events. Cochrane Database of Systematic Reviews 2017. DOI: 10.1002/14651858.cd005158.

49. Palacio S, Hart RG, Pearce LA, Anderson DC, Sharma M, Birnbaum LA, and Benavente OR. Effect of addition of clopidogrel to aspirin on stroke incidence: Meta-analysis of randomized trials. Int J Stroke 2015;10(5):686-691. DOI: $10.1111 /$ ijs. 12050 .

50. Hao Q, Tampi M, O'Donnell M, Foroutan P, Siemieniuk RAC, Guyatt G. Clopidogrel plus aspirin versus aspirin alone for acute minor ischaemic stroke or high risk transient ischaemic attack: systematic review and meta-analysis. BMJ 2018; 363:k5108 DOI: https://doi.org/10.1136/bmj.k5108.

51. Sudlow CL, Mason G, Maurice JB, Wedderburn CJ, Hankey GJ. Thienopyridine derivatives versus aspirin for preventing stroke and other serious vascular events in high vascular risk patients. Cochrane Database of Systematic Reviews 2009. DOI: 10.1002/14651858.cd001246.

52. Kwok CS, Shoamanesh A, Copley HC, Myint PK, Loke YK, Benavente OR. Efficacy of antiplatelet therapy in secondary prevention following lacunar stroke: pooled analysis of randomized trials. Stroke 2015;46:1014-1023.

53. Han SW, Lee SS, Kim SH, Lee JH, Kim GS, Kim O-J, Koh L-S, Lee JY, Suk S-H, Lee SI, Nam HS, Kim W-J, Yong SW, Lee K-Y, Park JH. Effect of cilostazol in acute lacunar infarction based on pulsatility index of transcranial Doppler (ECLIPse): a multicenter, randomized, double-blind, placebo controlled trial. Eur Neurol 2013;69:33-40.

54. Yi X, Zhou Q, Lin J, Chi L. Aspirin resistance in Chinese stroke patients increased the rate of recurrent stroke and other vascular events. Int J Stroke 2013;8(7):535-539. DOI: $10.1111 / j .1747-4949.2012 .00929$.

55. Depta JP, Fowler J, Novak E, Katzan I, Bakdash S, Kottke-Marchant K, Bhatt DL. Clinical outcomes using a platelet function-guided approach for secondary prevention in patients with ischemic stroke or transient ischemic attack. Stroke 2012;43 (9):2376-2381.

56. Campuzano Maya G. Resistencia a la aspirina: un problema latente de alto riesǵo. Med Lab 2016;22:13-54.

57. Campuzano Maya G. Inhibidores del receptor plaquetario P2Y $\mathrm{Y}_{12}$ Parte 2 de 2. Etiología, Diaǵnóstico y manejo de la resistencia. Med Lab 2017;23:113-148.

58. Lee M, Saver JL, Hong KS, Rao NM, Wu YL, Ovbiagele B. Antiplatelet regimen for patients with breakthrough strokes while on aspirin: a systematic review and metaanalysis. Stroke 2017;48 (9):2610-2613.

59. Chin CT, Neely B, Ohman M, Armstrong PW, Corbalán R, White HD, Prabhakaran D, J. Winters KJ, Fox KAA Roe MT, for the 
TRILOGY ACS Investigators. Time-varying effects of prasugrel versus clopidogrel on the long-term risks of stroke after acute coronary syndromes. Results from the TRILOGY ACS Trial. Stroke 2016;47:1135-1139. DOI: 10.1161/STROKEAHA.115.012454.

60. Wang Y, Pan Y, Zhao X, Li H, Wang D, Johnston $\mathrm{SC}$, Liu L, Meng $\mathrm{X}$, Wang $\mathrm{A}$, Wang $\mathrm{C}$, Wang $\mathrm{Y}$. Clopidogrel with aspirin in acute minor stroke or transient ischemic attack (CHANCE) Trial one-year outcomes on behalf of the CHANCE Investigators. Circulation 2015;132:40-46. DOI: 10.1161/CIRCULATIONAHA.114.014791).

61. Pan Y, Jing J, Chen W, Meng X, Li H, Zhao $\mathrm{X}$, CHANCE investigators. Risks and benefits of clopidogrel-aspirin in minor stroke or TIA Time course analysis of CHANCE. Neurology 2017;88:1906-1911.

62. Del Brutto VJ, Chaturvedi S, Diener HS, Romano JG, Saceo RL. Antithrombotic therapy to prevent recurrent strokes in ischemic cerebrovascular disease. $\mathrm{J} \mathrm{Am}$ Coll Cardiol 2019;74:786-803.

63. Kheiri B, Osman M, Abdalla A, Haykal T, Swaid B, Ahmed S, Chahine A, Hassan M, Bachuwa G, Al Qasmi M, Bhatt DL. Clopidogrel and aspirin after ischemic stroke or transient ischemic attack: an updated systematic review and meta-analysis of randomized clinical trials. J Thromb Thrombolysis 2019;47(2):233-247. DOI: 10.1007/ s11239-018-1786-\%.
64. Ye MB, Chen YL, Wang Q, An J, Ye F, Jing P. Aspirin plus clopidogrel versus aspirin monotherapy for ischemic stroke: a meta-analysis. Seand Cardiovase J 2019;53(4):169-175. DOI: 10.1080/14017431.2019.1620962.

65. Geeganage CM, Diener HC, Algra A, Chen C, Topol EJ, Dengler R, Markus HS, Bath MW, Bath PM. Acute antiplatelet stroke trialists collaboration. Dual or mono antiplatelet therapy for patients with acute ischemic stroke or transient ischemic attack: systematic review and meta-analysis of randomized controlled trials. Stroke 2012;43(4):1058-1066. DOI: 10.1161/ STROKEAHA.111.637686.

66. Gouya G, Arrich J, Wolzt M, Huber K, Verheugt FW, Gurbel PA, Pirker-Kees A, Siller-Matula JM. Antiplatelet treatment for prevention of cerebrovascular events in patients with vascular diseases: a systematic review and meta-analysis. Stroke 2014;45(2):492-503. DOI: 10.1161/STRO KEAHA.113.002590. 